\title{
orang sUNDA perantaU. TINJAUAN DALAM CARITA PANTUN
}

\section{SUNDANESE TRADITION OF WANDERER: A REVIEW IN CARITA PANTUN}

\author{
Yuzar Purnama \\ Balai Pelestarian Nilai Budaya Jawa Barat \\ Jl. Cinambo No. 136, Ujungberung, Bandung. \\ e-mail: yuzarpurnama@gmail.com
}

Naskah Diterima: 5 September 2019

Naskah Direvisi: 16 Maret 2020

Naskah Disetujui :18 April 2020

DOI: 10.30959/patanjala.v12i1.566

\begin{abstract}
Abstrak
Orang Sunda cenderung dikenal sebagai masyarakat yang tinggal di pedalaman/dataran tinggi. Masyarakat Sunda adalah salah satu etnis yang ada di Nusantara, dan termasuk etnis kedua terbesar jumlah penduduknya setelah etnis Jawa. Masyarakat Sunda dapat dikatakan merupakan penduduk yang tinggal di Provinsi Jawa Barat dan Provinsi Banten. Ciri umum masyarakat Sunda adalah berbahasa Sunda dan memiliki budaya Sunda. Penelitian ini ingin membuktikan, apakah benar orang Sunda itu perantau? Artikel ini membatasi objek penelitian pada carita pantun Sunda. Penelitian ini menggunakan metode deskriptif dengan pendekatan kualitatif. Berdasarkan carita pantun, dapat diperoleh kesimpulan bahwa para tokoh utama dalam cerita melakukan perjalanan (merantau) dengan berbagai tujuan, yaitu mencari wilayah untuk mendirikan kerajaan baru, mencari pendamping hidup (istri), menyelamatkan dari penculikan, dan peperangan untuk memperluas kekuasaan kerajaan.
\end{abstract}

Kata kunci: masyarakat Sunda, perantau, carita pantun.

\begin{abstract}
Sundanese tend to be known as people living in hinterland as well as highland region. They are an ethnic group native to Indonesia. As ethnic group, they are Indonesia's second most populous ones, after the neighboring Javanese. They have traditionally been concentrated in the provinces of West Java and Banten. Their general characteristics include Sundanese language and culture. The research aims to prove whether Sundanese carried on a wanderer tradition. The journal focuses on Carita Pantun as its research object. A descriptive analytic with a qualitative approach has been used as the basic method of the research. In reference to Carita Pantun, it leads to a conclusion that the main characters in Carita Pantun wander for purposes, that is, managing to establish a new kingdom, looking for a life companion, escaping from kidnappers, and serving a war of expanding empire.
\end{abstract}

Keywords: Sundanese, wanderer, carita pantun.

\section{A. PENDAHULUAN}

Etnis Sunda $(40,06 \%)$ merupakan etnis terbesar kedua setelah etnis Jawa $(15,51 \%)$ di wilayah Republik Indonesia. Hasil identifikasi Ananta dan kawan-kawan pada tahun 2014, sebanyak 15 kelompok suku besar di Indonesia menunjukkan bahwa proporsi terbesar adalah etnis Jawa sebesar
40 persen, diikuti etnis Sunda dan Melayu masing-masing 15,5 persen dan 3,7 persen. Sementara dari lima belas etnis tersebut, proporsi terendah adalah etnis Cina sebesar 1,2 persen. Kelompok suku kecil yang tergabung dalam kategori "lainnya" sebagian besar berasal dari wilayah timur Indonesia (Raharja, 2017: 73). 
Etnis Sunda sebagian besar tinggal di Provinsi Jawa Barat dan Provinsi Banten. Namun demikian, perseberannya merata hampir di seluruh wilayah Nusantara. Ada etnis Sunda yang bermukim Provinsi Lampung sampai ke Provinsi Aceh, Jawa Tengah, Jawa Timur, Bali, Kalimantan, Sulawesi, Maluku, Nusa Tenggara, sampai ke wilayah paling timur NKRI yaitu pulau Irian Jaya (Papua).

Ciri implisit etnis Sunda sehariharinya menggunakan bahasa Sunda dan memiliki mata budaya yang cukup dikenal baik di dalam negeri maupun mancanegara, seperti kesenian jaipong dan angklung. Selain itu, etnis Sunda kaya dengan kebudayaannya, mulai dari kuliner: lotek, rujak, bajigur, bandrek, karedok, soto Bandung, peuyeum, colenak, lalablalaban, sayur asem, sayur lodeh, bubur lemu, bubur kacang hejo, nasi timbel, nasi liwet, nasi tutug oncom, tumis genjer oncom, pepes ikan, bakakak hayam, gepuk, sate maranggi, laksa bogor, doclang, kupat tahu, asinan bogor, geco (toge dan tauco), surabi, tahu sumedang, dodol garut, leupeut, comro, misro, awug, bapatong (baso kupat gentong), cungkring, angeun lompong, buntil, kekedemes, dan sebagainya. Beragam busana: kebaya, pangsi, kain dodot, kampret, sarung kebat dilepet, karembong, calana komprang, iket (barangbang semplak, hanjuang nangtung), baju salontreng, baju bedahan, jas beludru sulam benang emas (menak), beskap (pakain resmi), dan busana pengantin yaitu kebaya brokat dan kain batik kebat lereng eneng prada serta jas buka prangwedana. Berbagai upacara adat Sunda seperti upacara seren taun, tutup taun, labuh saji, ngalungsurkeun pusaka, ngunjung/munjung, bubur syuro, ngiran (rebo wekasan), opat bulanan, nujuh bulanan, salapan bulanan, reuneuh mundingeun, memelihara tembuni, nenjrag bumi, puput pusar, ekah, nyangku, nurunkeun, cukuran (marhabaan), turun taneuh, gusaran, sepitan/sunatan. Berbagai jenis kesenian tradisional seperti wayang golek, calung, degung, rampak gendang, sisingaan, kuda renggong, bajidoran, sintren, cianjuran, kacapi suling, ciawian, reog, dogdog lojor, angklung buhun, debus, karinding, dan carita pantun. Sebenarnya masih sangat banyak mata budaya khas masyarakat Sunda, namun hanya sebagian saja diketengahkan untuk sekedar mengenal budaya masyarakat Sunda.

Kesenian atau tradisi lisan carita pantun yang dijadikan sampel dalam penelitian ini untuk melihat apakah masyarakat Sunda itu masyarakat perantau? Dalam perjalanan hidup dan kehidupan ini masyarakat paham benar bahwa etnis yang termasuk sebagai perantau di antaranya etnis Minangkabau (Padang), Cina, Arab, Bugis, dan Jawa. Oleh karena kebudayaan mereka mendukung ke sana serta mobilisasi keluar daerah relatif cukup besar. Hampir di setiap wilayah eksistensi mereka relatif menonjol dan masyarakat sudah tidak asing serta menerimanya.

Sementara itu pada masyarakat Sunda ada pepatah "bengkung ngariung, bongkok ngaronyok", "dahar teu dahar asal kumpul" (makan tidak makan yang penting kumpul) maksudnya berkumpul dalam keluarga itu lebih baik. Makan tidak makan yang penting bisa berkumpul. Dalam ungkapan lain jika ada orang Sunda marah lazim terucap ungkapan "Jig cing jauh ka sabrang ka Palembang" (Pergilah yang jauh ke seberang ke Palembang). Berdasarkan ungkapan tersebut bahwa masyarakat Sunda itu bukanlah berjiwa sebagai perantau. Namun demikian, dalam realitanya relatif cukup banyak orang Sunda yang hidup di luar habitatnya (Jawa Barat dan Banten). Mereka bermukim tetap dan sementara di Sumatera, Sulawesi, Jawa Tengah, Jawa Timur, Bali, Kalimantan, Nusa Tenggara, Maluku, dan Papua, bahkan ada yang bermukim di Negeri Malaysia, Arab Saudi, dan negara lainnya. Inilah yang menarik untuk diteliti. Adapun yang menjadi sampel kajian adalah dalam tradisi lisan carita pantun, 
karena disinyalir bahwa mata budaya ini merupakan budaya asli masyarakat Sunda.

Adapun tujuan penelitian ini adalah untuk mendapatkan gambaran yang lengkap dan jelas tentang masyarakat Sunda, benarkah masyarakat Sunda itu perantau?

Menurut Ekadjati (2005: 1) sebagaimana ia mengutip pernyataan Ajip Rosidi, bahwa menyebut orang Sunda adalah "orang yang mengakui dirinya dan diakui oleh orang lain sebagai orang Sunda". Ditinjau dari sudut kebudayaan, orang Sunda adalah "orang atau kelompok orang yang dibesarkan dalam lingkungan sosial budaya Sunda serta dalam hidupnya menghayati dan menggunakan normanorma dan nilai-nilai budaya Sunda" (Muhsin Z, 2011:11).

Kata "Sunda" dalam Kamus Besar Bahasa Indonesia (KBBI) adalah suku bangsa yang mendiami daerah Jawa Barat; bahasa yang dituturkan oleh suku Sunda (Sugono, 2013:1355). Kata Sunda berasal dari bahasa Sanskerta yang artinya cahaya atau air. Sunda berasal dari kata sudha (Sanskerta) artinya terang benderang/putih bersih. Rosidi (2000) mengatakan bahwa berdasarkan data arkeologis, tanah Sunda telah dihuni oleh masyarakat Sunda sejak lama sebelum tarikh Masehi. Situs Purbakala di Ciampea (Bogor), Klapa Dua (Jakarta), Cibuaya (Karawang), Cipari (Kuningan), dataran tinggi Bandung, dan Cangkuang (Garut) memberi bukti dan informasi bahwa lokasi-lokasi tersebut telah ditempati kelompok masyarakat yang memiliki sistem kepercayaan, organisasi sosial, sistem mata pencaharian, pola pemukiman, dan lain-lain sebagai layaknya kehidupan masyarakat manusia betapapun sederhananya. Era sejarah di tanah Sunda baru dimulai pertengahan abad ke-5 seiring dengan dibuatnya dokumen tertulis berupa beberapa buah prasasti yang dipahat pada batu dengan menggunakan bahasa Sanskerta dan aksara Pallawa. Prasastiprasasti itu yang ditemukan di daerah Bogor, Bekasi, dan Pandeglang dibuat pada zaman Kerajaan Tarumanagara salah satu rajanya bernama Purnawarman dan ibukotanya terletak di Bekasi sekarang (Rosidi, 2000: 619).

Berdasarkan catatan sejarah, Sunda dimulai dari zaman kerajaan yang berkuasa pada waktu itu mulai dari Kerajaan Salakanagara (130-362 M) kemudian zaman Kerajaan Tarumanagara (358-669 M), zaman Kerajaan Kendan hingga Galuh (536- 852 M), zaman Kerajaan Sunda (669 -1482 M), dan zaman Kerajaan Sunda Padjadjaran (1482-1579 M). Yulipar (2018: 476) menyebutkan bahwa Kerajaan Sunda berkuasa dari tahun 670-1579/80 M (Muhsin Z, 2011: 20).

Arti kata "rantau" dalam Kamus Besar Bahasa Indonesia adalah daerah (negeri) di luar derah atau negeri sendiri atau daerah (negeri) di luar kampung halaman; negeri asing. Merantau adalah pergi ke negeri lain untuk mencari penghidupan, ilmu, dan sebagainya. Perantau adalah orang yang mencari penghidupan, ilmu, dan sebagainya di negeri lain; orang asing; pengembara. Perantauan adalah negeri lain tempat mencari penghidupan; daerah yang didiami oleh orang yang berasal dari daerah lain (Sugono, 2013: 1143).

Merantau merupakan kegiatan yang dilakukan oleh seseorang yang meninggalkan kampung halamannya atas kemauan sendiri dalam jangka waktu yang telah ditentukan dan dengan tujuan mencari penghidupan, menuntut ilmu atau mencari pengalaman sebagaimana dikemukakan Sari (2018: 1) yang mengutip pernyataan Mochtar Naim. Para pendatang ini merasa bahwa di daerah asalnya masih belum bisa memenuhi kebutuhan-kebutuhan tersebut terutama yang berkaitan dengan pemenuhan kebutuhan atau pendapatan di masa depan. Hal ini yang biasa disebut merantau (Sari, 2018: 1). Merantau merupakan salah satu jalan keluar bagi individu untuk meningkatkan kualitas diri (Utami, 2018: 1).

Konsep merantau mengacu pada konsep migrasi sirkuler, yaitu migrasi tidak 
tetap. Migrasi sirkuler didefinisikan sebagai perginya penduduk keluar melewati batas administrasi desa asal pada waktu tertentu untuk mencari pekerjaan tanpa diikuti oleh perpindahan tempat tinggal (Djunaedi, 1995:1). Tentunya apabila ada migrasi yang tidak diikuti perpindahan tempat tinggal, maka akan ada migrasi yang diikuti dengan perpindahan tempat tinggal. Selanjutnya, Djunaedi (1995) menjelaskan bahwa ada faktor pendorong atau penarik untuk terjadinya migrasi (merantau) seperti halnya masyarakat Sunda Desa Cisayong Kabupaten Tasikmalaya. Faktor pendorong seperti faktor ekologis, faktor ekonomi dan demografi, faktor pendidikan, faktor keresahan politik serta faktor sosial. Sementara faktor penariknya adalah daya tarik kota yang menjanjikan harapan memperoleh nafkah. Selain itu, seorang perantau tidak saja akan menambah penghasilan, tetapi juga mendudukkan mereka pada strata yang terpandang (Djunaedi, 1995: 1).

Dalam Undang-undang Pemajuan Kebudayaan disebutkan bahwa tradisi atau budaya itu di antaranya adalah tradisi lisan. Menurut Yeni (2012: 407) tradisi lisan adalah warisan leluhur yang banyak menyimpan kearifan lokal, kebijakan, dan filosofi hidup yang terekspresikan dalam bentuk mantera, petatah-petitih, pertunjukan, dan upacara adat. Tradisi lisan yang terdapat di Nusantara, sekaligus juga menyimpan identitas bangsa karena pada tradisi lisan terletak akar budaya dan akar tradisi sebagai subkultur Indonesia.

Salah satu jenis tradisi lisan pada masyarakat Sunda adalah carita pantun. Cerita pantun merupakan salah satu genre sastra lisan Sunda yang keberadaannya sudah hampir punah. Cerita pantun merupakan salah satu hasil sastra lisan Sunda asli yang sudah tercatat keberadaannya dalam naskah Sunda kuno Sanghyang Siksa Kanda $\mathrm{Ng}$ Karesian bertiti mangsa 1440 Saka/1518 Masehi (Atja dan Danasasmita, 1981: 40).

Pada umumnya carita pantun mengisahkan cerita masa lalu (baheula) tentang raja-raja atau putra-putra raja keturunan Pajajaran. Bertolak dari isi ceritanya yang banyak mengisahkan kebesaran dan keagungan Raja Pajajaran, Prabu Siliwangi, diduga bahwa carita pantun ini lahir pada zaman Pajajaran. Akan tetapi ada pula carita pantun yang mengisahkan kebesaran dan keagungan keagungan kerajaan yang lebih tua, yaitu Kerajaan Pasir Batang Anu Girang dalam carita pantun Lutung Kasarung dan Kerajaan Galuh dalam carita pantun Ciung Wanara yang telah berdiri jauh lebih dahulu daripada Kerajaan Pajajaran (Koswara, 2013: 34).

Menurut Ajip Rosidi (1966) yang dimaksud dengan carita pantun adalah semacam cerita yang dideklamasikan oleh juru pantun sambil diiringi oleh petikan pantun yaitu semacam kecapi yang bentuknya seperti perahu. Biasanya carita pantun itu dideklamasikan sepanjang malam, dimulai sejak bada salat isa dan diakhiri menjelang saalat subuh. Pendeklamasian itu dilakukan di luar kepala (Ajip Rosidi, 1966:1).

Perbedaan antara carita pantun pada masyarakat Sunda dengan pantun pada masyarakat Melayu, substansinya sangat berbeda. Pantun melayu adalah syair yang terdiri atas beberapa baris dalam satu bait. Pantun terdiri atas kalimat sampiran (kiasan) dan isi, misalnya "Dahulu parang, sekarang besi, dahulu sayang sekarang benci". Pada masyarakat Sunda jenis sastra semacam ini dinamakan sisindiran, misalnya "Sapanjang jalan soreang diaspalan, sapanjang tacan kasorang diakalan" (Sepanjang jalan Soreang beraspal, sepanjang belum tercapai pasti diperjuangkan).

Carita pantun yang tumbuh kembang dalam tradisi lisan masyarakat Sunda merupakan sebuah cerita panjang yang apabila disampaikan atau dilantunkan oleh juru pantun (pemantun) bisa menghabiskan waktu semalam suntuk. Kalimat yang digunakan adalah kalimat prosais, yaitu kalimat prosa yang memiliki keindahan bunyi, seperti puisi tapi bukan. 
Carita pantun bentuknya narasi yang menceritakan seorang tokoh atau beberapa tokoh dalam sebuah kerajaan. Pada umumnya tokoh cerita yang dikisahkan adalah para raja dan keturunan Raja Prabu Siliwangi dari Kerajaan Pajajaran.

\section{B. METODE PENELITIAN}

Penelitian ini menggunakan metode deskriptif dengan pendekatan kualitatif. Intani (2011: 123) menyebutkan bahwa metode deskriptif adalah mendeskripsikan secara rinci untuk fenomena sosial tertentu. Sejalan dengan itu bahwa metode deskriptif merupakan kegiatan untuk mengetahui dan menggambarkan fenomena sosial tertentu, dengan mengumpulkan data dan melukiskan sebagaimana adanya, dan melakukan penelaahan data untuk memecahkan masalah dalam sebuah penelitian. Metode deskriptif adalah penelaahan data yang memecahkan masalah yang tidak terbatas pada pengumpulan dan penyusunan namunsampai pada kesimpulan yang didasarkan atas penelitian (Surakhmad, 1982: 19).

Adapun pendekatan penelitian kualitatif adalah prosedur penelitian yang menghasilkan data deskriptif berupa katakata tertulis atau lisan dari orang-orang dan perilaku yang dapat diamati (Bogdan, 1972: 5). Kemudian Moleong (1989: 7) mengatakan bahwa pendekatan kualitatif adalah pendekatan yang didasarkan pada data yang dikumpulkan berupa kata-kata, gambar, dan bukan angka-angka. Selanjutnya, pada penelitian kualitatif, teori dibatasi pada pengertian: suatu pernyataan sistematis yang berkaitan dengan seperangkat proposisi yang berasal dari data dan diuji kembali secara empiris (Moleong, 1989: 9).

Langkah-langkah dalam penelitian ini dimulai dari pengambilan sumber rujukan yang berasal dari buku-buku yang berkaitan dengan data, yaitu jurnal penelitian, sumber website, dan lain sebagainya. Selanjutnya pengambilan data untuk diklasifikasi, dianalisis, dan diakhiri dengan penulisan hasil penelitian.

Pencarian data dimulai dengan mengumpulkan beberapa teks carita pantun yang dianggap mewakili carita pantun, kemudian data dikumpulkan, diklasifikasi, dan dianalisis.

\section{HASIL DAN BAHASAN \\ 1. Sekilas Tradisi Lisan dan Carita Pantun}

Tradisi lisan merupakan salah satu khasanah kebudayaan bangsa Indonesia yang tumbuh kembang mulai dari Sabang (Aceh) sampai Merauke (Irian Jaya). Tradisi lisan atau cerita rakyat disebut folklor. James Danandjaya pada tahun 1972 mulai melakukan kajian mendalam tentang tradisi lisan yang diistilahkan dengan folklor Indonesia. Menurut Danandjaya sebagaimana dikutip oleh Pudentia (2015), menyatakan bahwa bahwa folklor adalah sebagian dari kebudayaan yang tersebar dan diwariskan turun temurun secara tradisional, di antara anggota-anggota kolektif apa saja di Indonesia, dalam versi yang berbeda-beda, baik dalam bentuk lisan maupun dalam bentuk contoh yang disertai dengan perbuatan-perbuatan dan alat-alat bantu pengingat, mnemonic devices.

Adapun tradisi lisan yang tumbuh kembang pada masyarakat Sunda di Jawa Barat adalah beluk, sisindiran, carita pantun, dan lain-lain. Dalam tulisan ini yang menjadi objek penelitian adalah tradisi lisan carita pantun. Alasannya karena carita pantun dianggap sebagai tradisi lisan milik masyarakat Sunda yang belum terpengaruh oleh budaya lain, contoh mata budaya wawacan dalam tradisi lisan Sunda yang mendapatkan pengaruh dari sastra Jawa. Selain itu, cerita dalam carita pantun sebagian besar mengisahkan para raja dan keturunan Raja Prabu Siliwangi, Raja Pajajaran yang dianggap sebagai leluhur orang Sunda. Purnama (2016: 190) menyebutkan bahwa carita pantun adalah sejenis kesenian tradisional dengan menampilkan seorang 
penutur (juru pantun) yang membawakan cerita seputar Kerajaan Pajajaran dengan diiringi alat musik kecapi.

Judul cerita dalam carita pantun relatif banyak, dalam penulisan ini hanya sepuluh (10) cerita carita pantun yang dijadikan sampel yaitu carita pantun yang berhasil didata dan dikumpulkan oleh J.J. Pleyte seorang pemerhati dan peneliti tradisi lisan di masa Pemerintahan Kolonial Belanda, J.J. Meijer, juru pantun Ki Samal dari lebak Wangi Kuningan, dan juru pantun Ki Asom dari Pringkasap Subang, carita pantun yang dimaksud adalah carita pantun Badak Pamalang, Gantangan Wangi, Kembang Panyarikan, Kidung Panandri, Kuda Wangi, Langgasari, dan Mundinglaya Di Kusumah, Raden Tanjung, dan carita pantun Panggung Karaton.

\section{Ringkasan Cerita dalam Carita Pantun}

Ringkasan data carita pantun yang akan ditulis pada sub bab ini hanyalah ringkasan singkat para tokoh utama carita pantun tersebut.

\section{a. Carita Pantun Kembang Panyarikan}

Kembang Panyarikan adalah raja di Negara Kutama Gancang. Baginda mempunyai adik seorang putri yang sangat cantik bernama Nyi Payung Agung Gelang Gading. Suatu ketika Kembang Panyarikan mendengar Raja Gangsal Wayang, Raden Aliman Sanjaya Guru Dewata, sedang mengadakan suatu kenduri besar dengan membakar kemenyan untuk mengundang para ksatria yang sanggup menolongnya mendapatkan Nyi Sumur Bandung, seorang putri dari Negara Kancana, adik Prabu Rangga Kancana. Bagi yang sanggup akan diangkat menjadi wakil raja. Ratu Kembang Panyarikan bertekad mengikuti sayembara tersebut, dan pamitan kepada adiknya. Dia pun berjanji akan mencari putra Pajajaran yang sedang mengembara ke arah Timur, bila bertemu akan menghadiahkannya untuk menjadi suami adiknya.
Akhirnya Ratu Kembang Panyarikan berhasil memboyong Nyi Sumur Bandung dari Negara Kuta Kancana dan berhasil pula menjodohkan adiknya dengan Prabu Aliman Sanjaya.

Sumber diperoleh dari cerita dari juru pantun Ki Samal, Lebakwangi Kuningan. (Carita pantun Kembang Panyarikan, dipantunkan oleh Ki Kamal, dipublikasikan oleh Ajip Rosidi tahun 1973, dan diterbitkaun oleh PPP\&F Sunda Bandung).

\section{b. Carita Pantun Gantangan Wangi}

Raden Gantangan Wangi Mangkurat Mangkunagara adalah putra Kangjeng Prabu Siliwangi, aja Pakuan Pajajaran dan telah dijadikan putra mahkota. Beliau ingin melamar Enden Cintawati, adik Raden Patih Jayanegara untuk menjadi istrinya. Kemudian ia pergi ke Negara Tilu Kuta Emas, untuk melamar Cintawati. Lamaran Gantangan Wangi diterima. Tak lama kemudian dilangsungkan pernikahan Gantangan Wangi dengan Cintawati

Namun demikian ada kendala, karena ada sebuah negara yang bernama Kuta Nusa Balitung yang rajanya bernama Gempur Alam yang menginginkan putri Cintawati menjadi tumbal "parepeh".

Raja mengutus dua kepercayaannya yaitu patih kerajaan yang bernama Rangga Sakti dan Rangga Kancana ditugasi membawa Cintawati ke Negara Kuta Nusa Balitung. Namun upayanya itu gagal karena Gempar Alam beserta kedua patihnya berhasil ditaklukkan oleh Jayanagara (kakak Cintawati) dan Gantang Pakuan (kakak Gantangan Wangi). Sebagai tanda gembira karena Cintawati telah kembali, negara telah aman sentosa seperti sediakala, diadakanlah pesta besar-besaran.

Sumber diperoleh dari Juru pantun Ki Asom, Pringkasap Subang 1973. (Carita pantun Gantangan Wangi, dipantunkan oleh Ki Asom, dipublikasikan oleh Ajip Rosidi taun 1973 dan diterbitkan oleh PPP\&F Sunda Bandung). 


\section{c. Carita Pantun Kidang Panandri}

Di Negara Pasir Batang Lembur Hilir memerintah seorang raja keturunan Ratu Pakuan Pajajaran, Prabu Rangga Malati. Beliau menginginkan putri dari Negara Pasir Batang Karang Tengah yang bernama Dewi Tulis untuk dijadikan permaisurinya. Dewi Tulis bersedia menjadi istri Prabu Rangga Malati, asal di Pasir Batang Lembur Hilir ada kuda berbulu burik yang ada di Nusa Bali.

Akhirnya diutuslah hulubalang kerajaan yang bernama Kidang Panandri dan berhasil mendapatkan binatang tersebut. Namun kakaknya Dewi Tulis yang bernama Kuda Jayang Sari dan Kuda Lanjar Saro tidak bersedia mengabdi kepada raja Pasir Batang Lembur Hilir serta tidak bersedia pula menikahkan Dewi Tulis kepada raja keturunan Ratu Pakuan Pajajaran.

Akhirnya terjadi pertempuran antara Kidang Panandri dengan Kuda Jayang Sari dan Kuda Lanjar Sari. Keduanya bisa dikalahkan dan bersedia mengabdikan diri. Lalu semuanya berangkat ke Negara Pasir Batang Lembur Hilir untuk menghadap kepada Prabu Rangga Malati.

Diadakanlah pesta besar-besaran menikahkan Prabu Rangga Malati dengan Dewi Tulis, dan pengangkatan Prabu Kuda Lanjar Sari menjadi patih Negara Pasir Batang Lembur Hilir. Negara Pasir Batang Lembur Hilir menjadi negara yang aman tenteram kerta raharja dengan hulubalang Kidang Panandri.

Sumber diperoleh dari Empat buah cerita pantun Sunda, Ed. J.J. Meijer. (Meijer, JJ, 1891 "Badoejsche Pantoen Verhalen" dalam Bidjragen tot de Taal-,Land- en Volkenkunde (BKI) Vol. 40 No.1 Hlm. 45105).

\section{d. Carita Pantun Mundinglaya Di Kusumah}

Prabu Siliwangi menjadi raja di Pajajaran, patihnya Kidang Kancana dan jaksanya Gelap Nyawang. Prabu Siliwangi memiliki istri bernama Nyi Padma Wati, suatu ketika istrinya ngidam dan menginginkan honje, namun honje tersebut diinginkan pula oleh putri yang sedang ngidam bernama Nyi Gambir di Babakan Muara Beres. Suatu ketika Nyi Gambir Wangi menginginkan terung pahit yang ingin dimakannya berbagi dengan Padma Wati, Prabu Siliwangi mencarikannya. Terung itu dibelah dua oleh Patih Gelap Nyawang, sesudahnya, raja bersabda kepada rakyatnya, bahwa bayi yang masih dalam kandungan itu sudah dikawinkan, menjadi jodohnya sebelum dilahirkan. Nyi Padmawati melahirkan seorang anak lakilaki yang bernama Mundinglaya Di Kusumah sedangkan Nyi Gambir melahirkan seorang putri yang bernama Dewi Asri.

Selanjutnya adalah perjalanan Mundinglaya untuk mendapatkan Dewi Asri menjadi istrinya mengalami hambatan dengan keinginan Sunten Jaya yang ingin memperistri Dewi Asri. Namun dengan perjalan waktu akhirnya Mundinglaya berhasil menikah dengan Dewi Asri karena sudah dijodohkan sejak dalam kandungan.

Sumber diperoleh dari Ed. C. M. Pleyte 1907. (Raden Moending Laja Di Koesoema dipublikasikan C.M. Pleyte tahun 1907, diterbitkan oleh Albreacht Bandoeng).

\section{e. Carita Pantun Badak Pamalang}

Badak Pamalang adalah putera Prabu Munding Malati dan Putri Geulis Aci Malati. Prabu Munding Malati adalah kakak (sepupu) Kasep Munding Sanggawati, putra mahkota Pajajaran yang berangkat mengembara ketika Badak Pamalang masih dikandung ibunya dan berusia satu bulan dalam kandungan. Ketika Badak Pamalang lahir, ia memperlihatkan kelainan-kelainan yang ajaib. Pertama, ia tidak dilahirkan dengan adanya darah dan cairan lainnya. Kedua, dia sangat mulus dan tampan. Ketiga, ia tidak memiliki pusar. Pada usia tiga hari secara ajaib ia menjerit-jerit minta diberi nama. Ibunya, Geulis Aci Malati berturutturut memberinya nama Prabu Kalang Kidang, kemudian Prabu Geulang Rarang. 
Ia tetap saja menangis. Demikian juga ketika diberi nama Prabu Sanggawaruling oleh dukun beranak.

Ayahandanya, Prabu Munding Malati kesal dan marah lalu mengambil bayi itu dan menendangnya jauh-jauh, dan jatuh pada ranting setangkai kembang cempaka warna.

Dari kahyangan, yaitu dari Gedung Sanghyang Nunggal turunlah nenenda mengambil bayi dan menimangnya sambil menyanyi. Lagu yang dinyanyikan berisi nasihat-nasihat, di antaranya tentang bilangan tahun, windu, bulan dan hari. Hari yang jumlahnya tujuh harus disatukan, manunggal pada diri sang bayi. Di samping itu nenenda mengharapkan bayi menjadi seorang pemberani, jadi lalaki langit lalanang jagat dan memberinya nama Badak Pamalang. Mendengar nama tersebut bayi terdiam dan tidur nyenyak di tangkai bunga campaka warna.

Tersebutlah seekor elang raksasa yang tak berbulu mencari makanan ke tempat itu. Elang ini adalah binatang peliharaan Demang Patih Naga Bali seorang bangsawan dari Negeri Nusa Bali. Badak Pamalang yang masih bayi ditemukan, lalu diambil dan dibawa ke Nusa Bali, di sana diberikan kepada anak elang itu. Maka sembilan bulan Badak Pamalang hidup di dalam perut anak elang.

Pada suatu kali ia keluar melalui dubur anak elang yang mati karenanya. Ia pun berhasil membunuh induknya. Karena sarang elang itu berada dalam kebun bunga, pemilik kebun bunga, yaitu Putri Lenggang Kancana, adiknya Demang Patih Naga Bali, ketika ia menemukan Badak Pamalang, ia tertarik dan memungutnya serta merawatnya dengan kasih sayang.

Akhirnya kehadiran Badak Pamalang diketahui dan ditemukan juga oleh Demang Patih Naga Bali. Demang Patih Naga Bali memutuskan untuk membunuh Badak Pamalang karena ia beranggapan Badak Pamalang adalah orang asing dan akan merusak Negara Nusa Bali. Namun setiap akan dibunuh,
Badak Pamalang tidak mempan senjata, akhirnya Demang Patih Naga Bali lari ketakutan.

Badak Pamalang mencari ibu angkatnya, Putri Lenggang Kancana. Setelah ditemukan lalu mereka pulang ke Kaputren Lenggang Kancana. Badak Pamalang diberi kawan bermain yaitu seekor ayam yang sakti yang bernama Kentri Haji Malang Dewa. Ayam ini dapat berbicara, dan dari ayam inilah Badak Pamalang mengetahui bahwa di Nusa Bali ada bangsawan-bangsawan (asing) yang dipenjarakan oleh penguasa Negara Nusa Bali. Badak Pamalang minta diantar Kentri ke penjara.

Badak Pamalang berhasil membuka penjara dan membebaskan para tahanan di antaranya Kasep Munding Sanggawati, putera mahkota Pajajaran yang juga pamandanya, beserta pengiring dan pembantunya, yaitu Ua Parawa Kalih, Ua Kidang Pananjung dan Jaksa Gelap Nyawang, serta istrinya Lenggang Pakuan. Ketika mereka saling memperkenalkan diri, tahulah Badak Pamalang bahwa mereka bukanlah orang lain.

Penyebab Kasep Munding Sanggawati dengan para pengiringnya ditangkap dan dipenjarakan oleh raja Nusa Bali karena melanggar nasihat orang tua, yaitu tidak hormat kepada tuan rumah. Meskipun sebenarnya keberangkatan rombongan itu dalam rangka persiapan Kasep Munding Sanggawati untuk menjadi raja yang sempurna.

Badak Pamalang memerangi Demang Patih Nusa Bali dan para ponggawanya yang terkenal gagah sakti, seperti Munding Rarangin dan Gajah Rarangin. Namun mereka dapat dikalahkan oleh Badak Pamalang. Akhirnya Kasep Munding Sanggawati menjadi raja di Nusa Bali.

Sumber diperoleh dari cerita Juru Pantun Ki Samid, Cisolok Sukabumi. (Carita pantun Badak Pamalang, dipantunkan oleh Ki Samid, Cisolok Sukabumi, 
dipublikasikan oleh Ajip Rosidi taun 1971, diterbitkan oleh PPP\&F Sunda Bandung).

\section{f. Carita Pantun Langgasari}

Prabu Langgasari adalah putra dari Kiai Pangrajam Girang, ibunya bernama Nyai Pangrajam, saudara misannya bernama Pangeran Simbar Kancana, dan adiknya yang cantik bernama Limbar Kancana. Alkisah Langgasari meninggalkan negara dan tinggal di Gunung Larang. Ia ngadunungan kepada Lenggang Manik. Suatu ketika kekurangan makanan, Lenggang Manik meminta makanan kepada Jamang Haji Jamang Kuning Jamang Beureum Jamang Hideung. Ia bukannya diberi, melainkan disiksa. Peristiwa itu terdengar oleh Prabu Langgasari, lalu ditantangnya berperang. Jamang Haji dapat ditaklukkan oleh Langgasari. Setelah itu Langgasari berangkat ke Negara Gunung Larang bersama-sama dengan Lenggang Manik. Ia menantang Gagak Larang dan berhasil menaklukkannya. Dari Gunung Larang mereka pergi menuju Pasir Batang, seorang ponggawa di Pasir Batang bernama Prabu Bagus Ratu Jaya mencoba mengadu kekuatan. Prabu Bagus Ratu Jaya berhasil ditaklukkan oleh Langgasari dan mengabdi kepada Langgasari. Akhirnya Langgasari tetap berada di Negara Pasir Batang.

Sumber diperoleh dari empat buah cerita pantun Sunda, Ed. J.J. Meijer. (Meijer, JJ, 1891 "Badoejsche Pantoen Verhalen" dalam Bidjragen tot de Taal-,Land-en Volkenkunde (BKI) Vol. 40 No.1 Hlm. 45105).

\section{g. Carita Pantun Kuda Wangi}

Putra Ratu Pakuan Pajajaran bernama Prabu Munding Liman. Permaisurinya bernama Lenggang Kancana. Ia memerintah di Pasir Batang, dibantu oleh ponggawanya bernama Kuda Kancana.

Pada suatu ketika Prabu Munding Liman ingin beristrikan seorang putri dari Gunung Wangi. Lalu pergilah ia bersama pengiringnya ke Gunung Wangi. Setelah sampai di kaki Gunung Wangi, Prabu Munding Liman beristirahat di padang rumput Ela Kandel.

Raja di Negara Gunung Wangi bernama Kuda Wangi, adiknya bernama Nyi Lenggang Wangi. Suatu hari ia pergi ke hutan bersama adiknya untuk menangkap puyuh. Akhirnya pertemuan pun terjadi antara Prabu dengan Nyi Langgeng Wangi. Oleh Prabu Kuda Wangi, adiknya dinikahkan dengan Prabu Munding Liman, dan untuk sementara tinggal papanggungan, di hutan Gunung Wangi. Selanjutnya pulang ke Pasir Batang dengan membawa Nyi Lenggang Wangi.

Kuda Wangi yang ditinggalkan di Gunung Wangi ingin berkelana dan ia melihat sebuah negara yang sangat indah, yaitu Negara Nusa Bini. Ia turun mencari kalau-kalau ada putri cantik atau raja yang gagah. Kemudian bertempur dengan raja Nusa Bini dan berhasil mengalahkannya. Kuda Wangi masuk ke Negara Pulo dan bertarung dengan rajanya. Pertempuran ini pun dimenangkannya.

Sumber diperoleh dari empat buah cerita pantun Sunda, Ed. J.J. Meijer. (Meijer, JJ, 1891 "Badoejsche Pantoen Verhalen" dalam Bidjragen tot de Taal-,Land- en Volkenkunde (BKI) Vol. 40 No.1 Hlm. 45105).

\section{h. Carita Pantun Raden Tanjung}

Raden Tanjung yang sedang bertapa di Sanghiang Pondok Pangrarambon dibangunkan oleh Raden Puspa Laya Mantri, dari Pajajaran yang menjadi raja di Negara Pasir Batang Pangrematan. Raden Tanjung dimintai pertolongan oleh Raden Puspa Laya Mantri untuk mengalahkan Kasep Gadung Lila Mantri yang mencuri prameswarinya, putri Palenggi Vina dan Sekar Cina. Berangkatlah Raden Tanjung ke Negara Rimpak Bitung dan berhasil mengalahkan Kasep Gadung Lila Mantri.

Raden Tanjung mendirikan negara di hulu negeri, disebutnya Babakan Kuta Waringin. Ratu Puspa Laya Mantri 
dijemput, dan berkumpullah semua punggawa, para istrinya, dan Raden Tanjung menjadi kepala pamuk.

Waktu Putri Palenggi Cina sedang mengandung, ia menginginkan buah pari kumbang yang berkulit emas, berbiji intan, milik Kebo Longkay Kalang Sinom. Raden Tanjung pergi mencarinya dibantu oleh saudaranya, Nyi Lutung Tunggal, Nu Geulis Nimbang Layaran, yang sedang bertapa di pohon jambu condong.

Dalam perjalanannya, Raden Tanjung terperosok ke dalam lumpur getah, kemudian harus melompati kancah malela yang airnya mendidih, dan akhirnya sampai ke Negara Buana Rarang. Raden Tanjung mengajak Putri Omprang Rarang dan saudaranya Gagak Karancang untuk mengabdi kepada menak Pajajaran, tetapi keduanya tidak patuh, maka Negara Buana Rarang dihancurkan.

Selanjutnya kembali ke Buana Panca Tengah, menemui Nyi Lutung Nunggal untuk mengambil buah pari kumbang. Setelah mengalami kesukaran untuk menembus pagar kawat dan pagar besi empat belas lapis, membunuhi amparampar putih, buah pari kumbang yang hanya sebiji itu berhasil didapatkannya setelah mengalahkan Kebo Longkay Kalang Sinom, pemilik buah pari kumbang.

Sumber diperoleh dari carita pantun Raden Tanjung dari juru pantun Ki Samid, Cisolok Sukabumi, tahun 1971. Carita pantun ini dipublikasikan oleh Ajip Rosidi taun 1971 dan diterbitkan oleh PPP \& F Sunda Bandung.

\section{i. Carita Pantun Panggung Karaton}

Negara Pakuan Pajajaran yang subur makmur dipimpin oleh rajanya Bayak Wide. Beliau memiliki seorang putra yang bernama Layung Batik. Banyak Wide menyuruh putranya mencari negara yang cocok dengan gambar nusa tigang puluh tiga, bangsawan sawidak lima, gagaman sajuta malang.
Tersebutlah di sebuah negara yang bernama Dayeuh Manggung, rajanya bernama Prabu Panggung Karaton yang mempunyai adik perempuan bernama Agan Bungsu Rarang Purbaratna Aci Kembang. Panggung Karaton merasa heran, meskipun banyak sekali yang melamar adiknya, namun adiknya tidak juga mau bersuami. Akhirnya diketahui, bahwa Bungsu Rarang hanya mau menikah dengan pria yang dapat memecahkan siloka yang selama ini mengganggu hatinya.

Maka diadakanlah sayembara, siapa yang berhasil memecahkan siloka itu akan dijadikan suami Bungsu Rarang. Tetapi tiada seorangpun dari semua putra mahkota atau raja semuanya yang dapat menebak makna siloka itu. Semuanya kembali dengan tangan hampa.

Layung Batik hampir putus asa, mencari negara yang sesuai dengan gambar, sampai akhirnya mau pulang. Namun di perjalanan pulang sampailah di Negara Dayeuh Manggung, negara ini cocok dengan gambar nusa tigang puluh tiga.

Pendek cerita Layung Batik bertemu dengan Patih Kalang Somantri dan dapat memahami arti mimpi itu. Akhirnya Layung Batik menikah dengan Bungsu Rarang. Sesudah pernikahan, Layung Batik diserahi kerajaan oleh Panggung Karaton, dan berganti nama menjadi Pangeran Surya Kancana Rat Sajagat.

Semua raja atau putera mahkota yang pernah ikut sayembara merasa sakit hati atas kekalahannya. Mereka ingin menghancurkan Negara Dayeuh Manggung begitu mendengar bahwa Bungsu Rarang telah menikah. Namun semuanya dapat diatasi oleh kesaktian Panggung Karaton. Semua raja dapat ditaklukkannya dan semua dijadikan ponggawa negara.

Tapi ada seorang raja yang merasa penasaran untuk memperoleh Bungsu Rarang yaitu Raden Pati Gajah Manggala, dari Kuta Ganggelang. Ia menyuruh Jurig Jonggrang Kalapitung menculik Bungsu 
Rarang. Akhirnya Panggung Karaton mencarinya dan terjadilah perkelahian yang sama-sama kuat, sama-sama gagah. Namun akhirnya Gajah Manggala dapat dikalahkan juga.

Sumber diperoleh dari carita pantun Panggung Karaton dari juru pantun $\mathrm{Ki}$ Atjeng Tamadipura, Situraja Sumedang. Cerita pantun ini dipublikasikan oleh Ajip Rosidi taun 1971 dan diterbitkan oleh PPP\&F Sunda Bandung.

\section{j. Carita Pantun Lutung Leutik}

Raden Bungsu Karmajaya bangsawan Pakuan Pajajaran, bermimpi bertemu dengan seorang gadis cantik jelita. Gadis tersebut adalah adik Tumenggung Laksa Gading dari Negara Nusa Gayonggong, namanya Bagendan Sari. Raden Bungsu minta izin kepada ibu dan ayahnya untuk pergi ke Negara Nusa Gayonggong dengan maksud mencari calon istri. Berangkatlah Raden Bagus dengan tujuan ke Nusa Gayonggong.

Tersebutlah Tumenggung Laksana Gading akan bertapa ke Ujung Kulon. Bagendan Sari dititipkan kepada Gajah Tarunajaya, raja Nagara Margacina. Setelah Gajah Taruna Jaya memanggil adiknya yang bernama Palenggi Rarang, ia meminta adiknya itu agar menerima Bagendan Sari sebagai saudaranya sendiri.

Raden Bungsu sampailah ke Negara Margacina, dengan terus terang disampaikannya maksud kepada Gajah Taruna Jaya, akhirnya mereka menikah.

Sumber diperoleh dari carita pantun Lutung Leutik dari juru pantun yang bernama Ki Kamal, Lebakwangi, Kabupaten Kuningan. Carita pantun Lutung Leutik dipublikasikan oleh Ajip Rosidi tahun 1973 dan diterbitkan oleh PPP \& F Sunda Bandung.

\section{Benarkah Orang Sunda Perantau?}

Dalam konsep yang dikemukakan pada bab pendahuluan dijelaskan bahwa orang yang dikategorikan sebagai perantau itu adalah orang yang mencari penghidupan; orang yang sedang mencari ilmu, dan sebagainya termasuk orang asing (KBBI). Kemudian ada beberapa faktor yang menyebabkan seseorang itu menjadi perantau yaitu orang-orang yang pergi dari tempat asal atau kelahirannya menuju tempat lain. Faktor yang dimaksud adalah tradisi atau budaya dari suatu kelompok etnis, juga ada faktor ekonomi, pendidikan, dan faktor peperangan.

Dalam carita pantun Kembang Panyarikan, tokoh cerita yang bernama Kembang Panyarikan adalah seorang raja Negara Kutama Gancang yang tergiur mengikuti sayembara yang diadakan oleh raja putra Pajajaran, Prabu Aliman Senjaya yaitu keinginan untuk menjadikan Nyi Sumur Bandung menjadi istrinya. Selain itu kepergiannya ingin menjodohkan adiknya menjadi istri putra Raja Pajajaran. Untuk meraih keinginannya ia harus pergi merantau ke beberapa negara (kerajaan) seperti Negara Gangsal Wayang, Negara Kuta Kancana, Negara Pamuruyan, Negara Buana Larang, dan Negara Buana Nyuncung, sampai akhirnya beliau mendapatkan yang diinginkannya. Atas jasanya ia diangkat menjadi wakil Raja Prabu Aliman Senjaya.

Dalam carita pantun Gantangan Wangi, tokoh cerita yaitu Gatangan Wangi putra mahkota Prabu Siliwangi berkehendak mempersunting Cintawati menjadi istrinya. Ia pergi merantau dari Kerajaan Pajajaran menuju Negara Tilu Kuta Emas untuk menikahi Putri Cintawati. Tidak lama kemudian Putri Cintawati diculik dan dibawa ke Negara Kuta Nusa Balitung. Akhirnya Gantang Pakuan, kakak Gantangan Wangi pergi merantau ke Kuta Nusa Balitung untuk mengambil kembali putri Cintawati. Gantang Pakuan melakukan pertempuran dengan raja Kuta Nusa Balitung, Gempur Alam dan adiknya yakni Rangga Sakti Mandraguna, Rangga Kemasandan Andon Kancana. Dalam pertempuran itu Raja Gempur Alam berhasil ditaklukkan dan Negara Kuta Nusa Balitung disatukan dengan Negara Tilu Kuta Emas. 
Dalam carita pantun Kidang Panandri, tokoh cerita yang bernama Kidang Panandri adalah seorang Hulubalang dari Kerajaan Pasir Batang Lembur Hilir, yang rajanya seorang keturunan Ratu Pakuan Pajajaran, Prabu Rangga Malati. Kidang Panandri diutus untuk mendapatkan binatang kuda berbulu burik yang ada di Nusa Bali. Kidang Panandri pergi merantau dari Negara Pasir Batang Lembur Hilir menuju Negara Nusa Bali untuk mengambil kuda berbulu burik sebagai syarat pernikahan yang diajukan Dewi Tulis. Pada akhirnya harus pergi merantau ke Negara Pasir Batang Negara Tengah untuk berperang menaklukkan rajanya yang tidak menyetujui adiknya, Dewi Tulis menikah dengan Prabu Rangga Malati, putra Ratu Pakuan Pajajaran.

Dalam carita pantun Mundinglaya Di Kusumah, tokoh cerita yang bernama Mundinglaya Di Kusumah berusaha mempertahankan calon istrinya yang bernama Dewi Asri yang sudah dijodohkan sejak dalam kandungan oleh ayahnya, Prabu Siliwangi. Mundinglaya Di Kusumah pergi dari Gunung Gumuruh ke Muara Beres untuk menikahi Dewi Asri yang mendapatkan tantangan dari Sunten Jaya. Namun sebelumnya Mundinglaya pergi merantau dari Gunung Gumuruh ke Leuwi Sipatahunan, Bangawan Cihaliwung dan ke Sangiang Patenggang untuk mencari Lalayang Kancana atas perintah neneknya Pohaci Wiru Mananggay.

Dalam carita pantun Badak Pamalang, tokoh cerita yaitu Badak Pamalang adalah keluarga besar Prabu Siliwangi yang memiliki kelainan. Dengan kelainannya itu, ia terdampar di Negara Nusa Bali. Setelah dewasa, Badak Pamalang pergi ke penjara di Nusa Bali untuk membebaskan orang-orang yang dipenjara. Ternyata yang dibebaskan pamannya yang bernama Prabu Kasep Munding Sanggawati beserta jajarannya yang ditangkap oleh Penguasa Nusa Bali, Demang Patih Naga Bali. Kemudian Badak Pamalang berhasil mengalahkan Demang Patih Naga Bali dan Kasep
Munding Sanggawati menjadi raja di Nusa Bali.

Kepergian Kasep Munding Sanggawati merantau ke Nusa Bali bertujuan untuk menjadi raja yang sempurna, namun nasib buruk menimpanya dan menyeretnya ke penjara karena dianggap tidak memiliki rasa hormat kepada tuan rumah.

Dalam carita pantun Langgasari, tokoh cerita Langgasari merantau ke Gunung Larang dan mengabdi kepada Lenggang Manik. Langgasari tidak terima ketika majikannya Lenggang Manik disiksa oleh Jamang Haji Jamang Kuning Jamang Beureum Jamang Hideung kemudian ditantang dan dibunuhnya. Peristiwa ini diadukan ke padaleman Gunung Larang dan semua penguasa Gunung Larang dapat ditaklukkannya. Kemudian pergi merantau ke Negara Pasir Batang dan berhasil pula menaklukkan ponggawa Pasir Batang yang bernama Prabu Bagus Ratu Jaya. Akhirnya Prabu Langgasari menetap di Pasir Batang.

Dalam carita pantun Kuda Wangi, tokoh cerita adalah Kuda Wangi yaitu seorang raja di Gunung Wangi. Setelah menikahkan adiknya yang bernama Nyi Lenggang Wangi dengan Putra Ratu Pakuan Pajajaran, bernama Prabu Munding Liman. Kemudian Kuda Wangi berkelana untuk mencari pengalaman dan wawasan yaitu ingin menantang mereka yang gagah. Ketika bertemu dengan raja Nusa Bali terjadilah pertempuran yang dimenangkannya, begitu pula ketika bertempur dengan Raja Pulo.

Dalam carita pantun Kuda Wangi, tokoh cerita Kuda Wangi adalah raja di Negara Gunung Wangi. Raja Kuda Wangi pergi ke Negara Nusa Bini dan Negara Pulo Kancana. Setelah berperang dan berhasil menaklukkan raja kedua negara tersebut, akhirnya wilayah Negara Nusa Bini dan Negera Pulo Kancana masuk di bawah kekuasaan Negara Gunung Wangi, dengan rajanya Prabu Kuda Wangi.

Dalam carita pantun Raden Tanjung, tokoh cerita Raden Tanjung 
adalah seorang ksatria petapa. Ketika sedang bertapa di Sanghiang Pondok Pangrarambon dibangunkan oleh Raden Puspa Laya Mantri mencari permaisuri Palenggi Vina dan Sekar Cina yang diculik oleh Kasep Gadung Lila. Berangkatlah Raden Tanjung untuk merantau ke Negara Rimpak Bitung untuk menyelamatkan permaisuri dari penculikan. Akhirnya terjadilah pertempuran dan berhasil mengalahkan Kasep Gadung Lila Mantri.

Dalam perantauannya itu Raden Tanjung berhasil mendirikan negara di hulu negeri yang disebut Negara Babakan Kuta Waringin. Di negara ini Ratu Puspa Laya Mantri memerintah dengan Raden Tanjung yang menjadi kepala pamuk.

Selanjutnya Raden Tanjung harus merantau ke Negara Buana Rarang kemudian ke Negara Buana Panca Tengah untuk mencari buah pari kumbang yang berkulit emas, berbiji intan, milik Kebo Longkay Kalang Sinom. Akhirnya buah pari kumbang berhasil didapatkan setelah mengalahkan Kebo Longkay Kalang Sinom, sebagai pemilik buah pari kumbang.

Dalam carita pantun Panggung Karaton, tokoh cerita Panggung Karaton adalah seorang raja di Kerajaan Dayeuh Manggung. Ia mempunyai seorang adik yang bernama Agan Bungsu Rarang Purbaratna Aci Kembang yang sedang mencari suami. Takdir menentukan adiknya menikah dengan Raden Layang Batik putra raja Kerajaan Pajajaran yang bernama Pangeran Banyak Wide. Akhirnya adiknya diculik oleh seorang raja yang bernama Raden Patih Gajah Manggala, dari Kuta Ganggelang, karena merasa penasaran dan sakit hati sudah kalah dalam sayembara. Akibatnya lebih jauh tidak mendapatkan putri cantik pujaan hatinya. Panggung Karaton selanjutnya pergi merantau ke Kerajaan Kuta Ganggelang untuk menyelamatkan adiknya yang diculik oleh Raden Patih Gajah Manggala. Akhirnya terjadi peperangan dan perkelahian seru yang dimenangkan oleh Raja Panggung Karaton.

Tokoh lainnya dalam carita pantun Panggung Karaton yang melakukan perantauan adalah Raden Layung Batik yang merantau ke Dayeuh Manggung untuk mencari seorang pendamping hidup. Akhirnya ia menikah dengan adik Panggung Karaton di Negara Dayeuh Manggung. Setelah menikah menjadi raja di Negara Dayeuh Manggung.

Dalam carita pantun Lutung Leutik, tokoh yang melakukan perjalanan adalah Raden Bungsu Karmajaya, bangsawan Pakuan Pajajaran. Ia melakukan perjalanan dan merantau karena ingin membuktikan mimpinya. Ia bermimpi bertemu dengan seorang gadis cantik jelita. Gadis tersebut adalah adik Tumenggung Laksa Gading dari Negara Nusa Gayonggong, bernama Bagendan Sari. Raden Bungsu minta izin kepada ibu dan ayahnya untuk pergi ke Negara Nusa Gayonggong dengan maksud mencari calon istri. Berangkatlah Raden Bagus dengan tujuan ke Nusa Gayonggong. Perjalanan dan perantauan Raden Bungsu tidak sebatas ke Negara Gayonggong namun melanjutkan ke Negara Margacina karena putri idamannya Bagendan Sari ada di sana.

Tokoh atau pelaku utama dalam carita pantun hampir semuanya melakukan pergi merantau dan meninggalkan tempat tinggal, tempat kelahiran, dan tempat wilayah kekuasaan untuk berbagai tujuan. Seperti, pergi mencari calon istri, pergi bertapa, pergi untuk membantu raja menghadapi huru-hara yang akan timbul, memperluas wilayah kekuasaan kerajaan, dan lain sebagainya. Menurut Soekanto sebagaimana dikutip oleh Heryana (2014: 164) bahwa yang dimaksud kekuasaan adalah kemampuan satu pihak (subjek kekuasaan) untuk mempengaruhi pihak lain (objek kekuasaan) sehingga pihak lain bertindak sesuai kehendak dan tujuan subjek kekuasaan (pemegang kekuasaan). 


\section{PENUTUP}

Manusia adalah makhluk sosial yaitu makhluk yang akan selalu berhubungan dengan orang lain dan makhluk yang akan saling bergantungan dengan orang lain. Tidak ada seorang pun manusia atau komunitas manusia yang bisa terlepas dari campur tangan orang lain.

Makhluk sosial tentunya dalam hidup dan kehidupannya selalu dinamis, bergerak, berkembang, beradaptasi, dan berkreasi. Salah satu ciri sifat manusia yang dinamis adalah melakukan pergerakan, di antaranya bergerak dalam arti bepergian. Bepergian ini bukan sekedar dari rumah keluar terus kembali lagi, akan tetapi pergi meninggalkan tempat tinggalnya; pergi meninggalkan tempat kelahirannya dan tidak kembali lagi karena menetap di wilayah lain yang relatif jauh dari tempat tinggal semula. Bisa pula meninggalkan rumahnya atau tempat kelahirannya dalam jangka waktu lama, bertahun-tahun bahkan puluhan tahun, akan tetapi suatu waktu kembali lagi ke rumahnya atau ke tempat kelahirannya. Tentunya kepergiannya ini ada tujuan tertentu yang menjadi faktor pendorong atau penarik seperti halnya masyarakat Sunda. Faktor pendorong seperti faktor ekologis, faktor ekonomi dan demografi, faktor pendidikan, faktor keresahan politik dan faktor sosial. Juga faktor penarik yaitu daya tarik yang menjanjikan harapan memperoleh kehidupan yang lebih baik.

Bepergian semacam ini dalam Kamus Besar Bahasa Indonesia (KBBI) dapat dikategorikan merantau dan orang yang melakukannya disebut sebagai perantau. Dalam cerita yang terdapat dalam mata budaya carita pantun yang tumbuh kembang pada masyarakat Sunda, ternyata hampir seluruh tokoh atau pelaku utama melakukan tindakan meninggalkan tempat tinggal atau tempat kelahirannya untuk suatu tujuan yang jelas. Para tokoh sangat dinamis melakukan pergerakan dengan berbagai tujuan seperti kepergian seorang raja, ksatria, patih, hulubalang untuk memperluas kerajaan. Ada pula yang melakukan kegiatan merantau untuk mencari pendamping hidup, bertapa, dan keinginan luhur untuk membantu raja mengatasi huru-hara yang akan terjadi.

Dengan demikian jelaslah bahwa karakter orang Sunda yang digambarkan dalam tokoh atau pelaku utama narasi carita pantun adalah sebagai perantau. Maka tidaklah heran jika ada orang Sunda dapat tinggal sampai berketurunan di berbagai wilayah baik di wilayah Nusantara maupun di mancanagara dengan tujuan pekerjaan, mendapatkan jodoh, belajar, dan lain sebagainya.

Mengingat masih relatif cukup banyak cerita-cerita dalam tradisi lisan yang menggambarkan kehidupan manusia di masa lampau dan memiliki nilai budaya, maka perlu dilakukan penggalian dan penelitian dalam berbagai cerita dalam tradisi lisan agar dapat dijadikan pegangan, pedoman, dasar, pijakan, dan cermin tauladan khususnya bagi generasi muda.

\section{DAFTAR SUMBER}

Atja \& Danasasmita, S. (1981). Sanghyang Siksa Kanda Ng Karesian (Naskah Sunda Kuno Tahun 1518 Masehi). Jawa Barat: Proyek Pengembangan Permuseuman.

Bogdan, R. C. (1972). Participant Oberservation in Organizational Settings, Syracuse, N.Y.: Syracuse Univercity Press.

Djunaedi, E. (1995). Pola Merantau Masyarakat Dusun Cisayong Desa Cisayong Kecamatan Cisayong Kabupaten Tasikmalaya Jawa Barat : Studi Antropologi tentang Faktor-Faktor Pendorong dan Penarik Merantau Masyarakat Dusun Cisayong. Tesis Universitas Indonesia.

Ekadjati, E. S. (2005). Kebudayaan Sunda: Suatu Pendekatan Sejarah. Cetakan kedua. Jakarta: Pustaka Jaya

Heryana, A. (2014). Jejak Kepemimpinan Orang Sunda. Patanjala, 6 (2), 163178. 
Intani, R. (2011). Nilai Budaya pada Dolanan Dermayon. Patanjala, 3 (1), 119-135.

Koswara, D. (2013). Nilai-nilai Pendidikan Karakter Bangsa dalam Carita Pantun Mundinglaya Di Kusumah: Kajian Struktural-Semiotik dan Etnopeda-gogi. Metasastra, 6 (2), 33-48.

Meijer, J. J. (1891). Badoejsche Pantoen Verhalen. Bidjragen tot de Taal-Landen Volkenkunde (BKI), 40 (1), 45-105.

Moleong, L. J. (1989). Metodologi Pe-nelitian Kualitatif. Bandung: Remaja Karya.

Muhsin Z., M. (2011). Kajian Identifikasi Permasalahan Kebudayaan Sunda (Masa Lalu, Masa Kini, dan Masa yang Akan Datang). Bandung: Universitas Padjadjaran.

Mulyani, Yeni. (2012). Tradisi Lisan dan Identitas Bangsa, Studi Kasus Kampung Adat Sinarresmi, Sukabumi. Patanjala, 4 (3), 407-418.

Pleyte, C. M. (1907). Raden Moending Laja Di Koesoema. Bandung: Albreacht Bandoeng.

Pudentia (Ed). (2015) Metodologi Kajian Tradisi Lisan. Jakarta: Obor.

Purnama, Y. (2016). Kajian Nilai Budaya dalam Carita Pantun Sawung Galing. Patanjala, 8 (2), 187-202.

Raharja, M. B. (2017). Fertilitas Menu-rut Etnis di Indonesia. Jurnal Kependudukan Indonesia, 12 (1), 69-78.

Rosidi, A. (1966). Kesusasteraan Sunda Dewasa Ini. Cirebon: Tjupumanik.

(1971). Carita Pantun Badak Pamalang. Bandung: PPP\&F Sunda Bandung.

(1971). Carita Pantun Panggung Kara-ton. Bandung: PPP\&F Sunda Bandung.

(1971). Carita Pantun Raden Tandjung. Bandung: PPP\&F Sunda Bandung.

(1973). Carita Pantun Gantangan Wangi, dipantunkan oleh Ki Asom. Bandung: PPP\&F Sunda Bandung.
_. (1973). Carita Pantun Lutung Leutik. Bandung: PPP\&F Sunda Bandung.
. (1973). Carita Pantun Kembang Panjarikan, dipantunkan oleh Ki Kamal. Bandung: PPP\&F Sunda Bandung.

Rosidi, A. (Ketua). (2000). Ensiklopedi Sunda (Alam, Manusia, dan Budaya) termasuk Budaya Cirebon dan Betawi. Jakarta: Pustaka Jaya.

Sari, A. A. (2018). Kontrol Diri Mahasiwa Perantau dalam Menjaga Kepercayaan Orang Tua (Studi Kasus pada Mahasiswa Bimbingan dan Konseling Islam IAIN Purwokerto Angkatan 2017). Skripsi Institut Agama Islam Negeri (IAIN) Purwokwerto.

Sugono, D. (Ketua). (2013). Kamus Besar Bahasa Indonesia Pusat Bahasa. Jakarta: Gramedia Pustaka Utama.

Surakhmad, W. (1982). Penelitian Dasar Metode Teknis. Bandung: Tarsito.

Utami, A. W. (2018). Strategi Koping Mahasiswa Rantau Tahun Pertama Luar Pulau Jawa. Skripsi Universitas Muhammadiyah Sura-karta.

Yulifar, L. (2018). Kabuyutan Cipageran dari Zaman ke Zaman. Patanjala, 10 (3), 455-470. 
Patanjala, ISSN 2085-9937 (print), ISSN: 2598-1242 (online) 